\title{
The Underside of Communication in Development
}

\author{
Nora C. Quebral ${ }^{1}$
}

\begin{abstract}
Efforts to relate the concepts of human development and human communication are complicated by their processual nature. The fact that in most cases communication has become synonymous with media and the need to take contexts into account further complicate such efforts. How the two well-meaning concepts interact in both developing and developed countries with oftentimes unintended, or even unwanted, effects is the subject of this paper. The underside of communication in development is discussed as the failure to address those forms of poverty that threaten equality, social cohesion, and the free flow of knowledge and information.
\end{abstract}

Keywords: development, communication, media uses, gender

\section{Introduction}

Human development is a global imperative, but reflections about this are shaped by one's communication potential. The following views are from a Southeast Asian, domiciled in the Asia-Pacific region, who tries to keep up with development and communication events elsewhere in the world. The geographical bias shows up mainly in the examples used, although it is hoped that they are universal enough to resonate with everyone.

\section{Clearing Off}

Pairing two extra large concepts like "human development" and "human communication" constitutes a whole confusing underside in itself. Each can be looked at as process. In most cases, however, communication has become synonymous with media, and with the people who work in these industries. And today, media have split off into a variety of distinctions, such as old and new media; traditional, mainstream or legacy media; mobile media; electronic and digital media; social media. Mass media have become old hat, although community media seem to have fared better.

As for development, no longer is it just human or even participatory. Sustainable is the currently preferred modifier. Development can be inclusive, cultural, equitable or whatever the proponent deems it to be.

And then there is context, or the set of circumstances in which either communication or development or both operate. How the two well-meaning concepts interact in both developing and developed countries with oftentimes unintended, or even unwanted, effects is the subject of this article. 


\section{Power Abuser or Defender of the Poor?}

A developing society is a transitioning society. There are no clear demarcations between the old and the new. Strip off the modern veneer and the still largely feudal institutions lie just below the surface. Or they are so intermeshed that the whole is neither old nor new, but a unique entity altogether. It is not unlike "Taglish", a coined word denoting a mix of the English language and a dominant Filipino dialect that is Greek to outsiders but perfectly intelligible to most Filipinos.

Nowhere are these contradictions better seen than in a recent cause célèbre that centered on Sara D., a young mayor of a southern Philippine city, who had switched positions with her father who used to be mayor but was now the vice mayor ${ }^{2}$. The incident pitted her against a sheriff seeking to enforce a court order to demolish squatter shanties on land newly bought by a businessman. The area, along a river bank and within Sara's jurisdiction had been devastated by recent floods. She had in fact been distributing relief goods to the victims before arriving at the scene where the beleaguered residents, armed with improvised weapons, were standing their ground in defense of their homes.

Sara berated everyone equally: the demolition team, the villagers who then meekly submitted to her authority, the police called in to maintain order, and the insistent sheriff. She wanted the demolition delayed by two hours to give her time to calm the villagers and assure them of alternative housing. When the sheriff demurred, she punched him repeatedly with her fists, and thereby made all the metropolitan newspapers the next day. Sara was at first defiant but later apologized and went on leave while an investigation was going on, making her father the acting mayor. The latter took up the cudgels for his daughter, saying that she was right all along and that he was proud of her.

Public opinion - voiced through the different media - was divided ${ }^{3}$. No one is above the law; Sara was wrong to take the law into her own hands. Sara is a leader with balls; she was defending the poor and the underprivileged. As the mayor, Sara was justified in intervening because she prevented the violence from escalating. The law does require a month's notice before any demolition and the sheriff was misinformed, although Sara need not have been so physical.

A more thoughtful judgment came from Professor Randy David, a sociologist columnist who teaches at the University of the Philippines Diliman. Likening Sara to a folk hero in a pre-modern society, he reflected that the ensuing controversy would align people who insist on the immediate professionalization of government against those who understand that a strong godfather-like leadership is still needed in a society where the legitimacy of legal institutions is not yet accepted. In a highly unequal society, he continued, the rule of law cannot be impartial, and will always seem harsh. Instead of serving the ends of justice, it will seem to be another tool of oppression. Such a situation will thus still require the intervention of feudal leaders who can thereby extend their life spans.

In this transitional period, David believes that scions of the old power elite have an interesting role to play. Brought up in the traditional ways of feudal authority but also exposed to the norms of modern professional leadership, they can either be the rearguard of a dying feudal system or heralds of a new, less personal form of rule. Young leaders like Sara are precisely at this crossroad, according to David. 
To become agents of the modern, they need to think of their feudal birthright as no more than a ladder they need to climb to the top, which they must gradually discard as their constituencies become empowered to fight for their own rights. This is not an easy thing to do. In a society where the institutions are weak, such leaders often need to repeatedly validate their personal authority in the traditional way before they can begin to use it to give birth to the new. I want to think that Sara... is this kind of leader, and not just another goon ${ }^{4}$.

The foregoing tale is a snapshot in the development saga of a transitioning society. It also highlights an unfilled need for journalists who can put facts in social context and thereby help ease the passage to a more discerning society. Absenting the conditions for true modernity in the Asia-Pacific, media can serve an educational function in nonformal ways. Whether it does or not and whether it should or not are fit subjects for soul-searching in the communication schools of developing countries.

\section{The Un-Social Media}

Corruption maybe endemic in developing countries, but it exists as well in developed ones. For many, the new media, particularly social media, brings to mind images of connectivity, networking, young people, and the Arab Spring. For one British family, it meant a hacked-in mobile phone, questionable conduct by employees of a tabloid grandly named the "News of the World", and a young daughter murdered at 13 .

Milly D., a schoolgirl, had been missing for days and was feared dead by her parents. But messages on her voicemail deleted while the search for her was going on held out hope that she was still alive. As events later showed, a private investigator hired by the tabloid had illegally accessed her phone messages, erasing some when expedient, in pursuit of leads that could provide his employer an edge over competitors. The same tabloid was said to have similarly hacked into the phones of families of British soldiers killed in Iraq and Afghanistan. It was also alleged to have paid off the police for providing unauthorized information on some cases being investigated ${ }^{5}$.

The affair has since escalated into a major scandal that has tainted political leaders in high places, but in the beginning it was simply a case of one traditional communication medium using a new medium for unsocial purposes. Whether old or new, analog or digital, communication hardware and even software are neutral tools after all, designed to function in certain ways when duly programmed. The onus lies on their human user in any society. Fortunately, in this example the rule of law was initially upheld and the more visible culprits were jailed, which might not have happened in a transitioning society with looser penal standards. Nurturing the working ethos of professional communicators will always be a work in progress in both developed and developing countries.

\section{The Gender Equality Myth}

Whether external or internal, legal or illegal, migration is a coping mechanism for the poor in developing countries. It is a way of finding better-paying jobs and, in the case of overseas migration, a source of remittances to be sent to family back in the home country. Thousands of Indonesian and Filipino migrants now work in the Middle East, Europe, 
and other Asian countries. There are no accessible figures for Indonesia, but in 2011 the Philippines is said to have 18,789 nationals in Saudi Arabia employed as "household service workers"; 975 are males and 17,814 - or almost twice as many - are females ${ }^{6}$.

In July 2011, Saudi Arabia stopped hiring domestic workers from Indonesia and the Philippines ${ }^{7}$. The governments of both Asian countries had wanted guarantees of better wages, working conditions and human rights protection for their citizens. The freeze on hiring was taken as a sign of Saudi Arabia's objection to paying double the equivalent of \$200 that a domestic worker in Saudi was getting as monthly salary, and which she would already most likely be getting were she working in a middle-class home in Manila. It was also seen as foot-dragging by Saudi employers to allegations of abuse of domestic helpers. Some Filipino maids had reported good to tolerable working conditions in the Middle East in general, but others had cited instances of domestic slavery, like being made to work seven days a week with little food or rest, being locked up in rooms and not being allowed to go out, being forced to work for years until their contracts expired, and being subject to physical and sexual abuse. In spite of these reports of abuse and rape of household workers, Filipino women continue to leave the country for work abroad, according to a former Philippine labor undersecretary.

One such case is that of Elizabeth B., a Filipino maid in the employ of a United Arab Emirates naval officer. She testified at a trial in Rhode Island that her employer had brought her to the United States with his wife and five children, withheld her wages, and confined her to his house after warning her not to escape. She had previously worked for the family for three years at the UAE before her employer was sent to the US for further training. At a picnic that she went to with the family, she met a Filipino woman to whom she appealed to for help and to whom she gave her cell phone number. During cross-examination at the trial, she admitted that she did not read her contract before signing it, nor did she contact anyone before signing a document attesting that she had received 12 monthly payments of $\$ 1,600^{8}$.

In June 2011, the Saudi government had beheaded an Indonesian household helper who had been charged with murder. Indonesians were outraged especially because their government was not informed about the date of the execution. Another Indonesian maid, Darsem D. T., was also sentenced for beheading for killing her employer's male relative whom she said had tried to rape her. Faced with a strong public outcry, the Indonesian government paid two million riyals, or $\$ 533,000$, as "blood money" to the family of the slain man. Darsem was released and allowed to return to her family. Newspaper pictures showed her reunited with her young son, who was only a baby when she had left her village five years before for foreign employment ${ }^{9}$.

As a counterpoint to the plight of Asian female domestics is the news of a virtual revolt of Saudi women against the ban on their driving cars. In May 2011, Manal S. defied the ban and was accordingly put in prison for a week. In a matter of days, 500,000 viewers had watched her defiant drive on YouTube. Incensed by the ban, thousands of Saudi women vowed to stage a driving day to express their support for Manal.

Dr. Mai Yamani, a Saudi woman writer, provides contextual details on the issue: "Since January 2011, images of millions of [Saudi] women demonstrating alongside men have been beamed around the world by television journalists, posted on YouTube and splashed on the front pages of newspapers. One saw women from all walks of life marching in hope of a better future, for themselves and for their countries. They ap- 
peared prominently - eloquent and outspoken, marching daily, holding caricatures of dictators and chanting calls for democratic change. They walked, bussed, travelled in carts, telephoned and tweeted with compatriots, motivated in part by social demands, above all for their own empowerment." 10

In Saudi Arabia, women are not allowed to ride with men in elevators, to walk in the streets, or to leave the country without the permission of a male guardian. According to Dr. Yamani, Saudi Arabia is the only country in the world that forbids women to drive cars. The ban is not justified by Islamic texts, by the nature of the diverse Saudi society, or by the massive social upheaval occurring elsewhere in the region. Saudi women are not allowed to engage in the legal profession on the basis of a Wahhabi Restriction, which says that a woman is "lacking in mind and religion." In truth the law in Saudi Arabia effectively excludes women from the public sphere: "Saudi rulers have announced that demonstrations are haram - a sin punishable by jail and flogging. Now some clerics have pronounced driving by women to be foreign-inspired haram, punishable in the same way. Yet, despite such threats, thousands of Saudi women joined 'We are all Manal al Sharif' on Facebook, and countless other videos of women driving have appeared on YouTube since her arrest..."11

Implicit in the accounts of Asian and Middle East women is the existence of social networks that serve as social capital for the respective groups. Besides face-to-face encounters, these networks are maintained by mobile phones among the Asians and by computers and the internet among the well-off Middle East women. The socio-economic levels of the two groups of women are eons apart. The Saudis own cars, tweet on computers, and look up to tall skyscrapers. But they are not allowed to walk in the street, drive a car, or leave the country without a male relative. The Asians are free to seek jobs elsewhere, mainly as domestics often subject to abuse; to drive if they had cars; and to leave their country, although it means having their children nurtured by others for months or even years on end. A tough question to answer would be: in which society do women have more equal rights to communicate and to develop?

\section{Conclusion}

How development communication is perceived changes as new knowledge and insights are acquired. The latest definition of it in Los Baños is "the science of human communication linked to the transitioning of communities from poverty in all its forms to a dynamic state of overall growth that fosters equity and the advancement of individual potential" (C. Quebral, 2012). Given this definition, all societies are developing societies. The underside of the communication system in any society is failure to address those forms of poverty that threaten equality, social cohesion, and the free flow of knowledge and information.

Although economic development usually precedes corresponding advances in social development, the time lag appears more marked in today's developing countries. As may be expected, it is the poor and the disadvantaged who get the short end of the stick. Women in the Asia-Pacific generally fall into this category. In Hawaii, a growing number of deaths among Filipino migrants - a third of the adult cases - are caused by domestic violence, even though that ethnic group makes up only 14 percent of Hawaii's adult population ${ }^{12}$. According to a state social worker, one reason is that a Filipino 
woman who migrates to the US because of the citizenship status of her husband might feel obligated to him even when the relationship has turned sour. Cultural factors like religious beliefs, plus a reluctance to bring shame to the family and to subject children to a divorce, are other reasons for their keeping silent about abuse.

A recent "Newsweek" listing of the best places in the world for women ranked the Philippines in $17^{\text {th }}$ place with a score of 86.3 out of $100^{13}$. The Philippines was the only Asian country in the top 20, with Iceland, Sweden, Canada, and Denmark topping the list. The five areas considered in the scoring were treatment under the law, political power, work force participation, access to education, and access to health care. It is ironic that while all Filipino women occupy a fairly high standing in their own country, that advantage disappears when those with less in life migrate to other countries.

Our foregoing examples also indicate how the old and new media have become part of the warp and weft of the communication structures of all societies and communities. At the close of the day, however, it is still enlightened and caring individuals who can use their communication systems to help their societies and communities develop.

\section{Notes}

1. Nora C. Quebral is Professor Emeritus of Development Communication, University of the Philippines, Los Baños, and Honorary Doctor of Science (Social Sciences), LSE, UK. E-mail: nora_quebral@yahoo. com

2. Tulfo, Ramon (July 5, 2011), "Her father's daughter" (In on Target), Philippine Daily Inquirer.

3. See Philippine Daily Inquirer, "Not my best moment, says Duterte of incident", July 3, 2011; "Inday Sarado" (editorial), July 4, 2011; "Inday Sara praised by 'Punisher"”, July 4, 2011; "Sara's punch line: No need for demolition," July 6, 2011; "Davao judge 'shoots' the sheriff," July 9, 2011.

4. David, Randy (July 3, 2011), "Sara and the sheriff" (In Public Lives), Philippine Daily Inquirer.

5. Poniewozik, James, "The Humbling of Rupert Murdoch," Time, vol. 178, No. 5/2011, p. 32.

6. Tubeza, Philip C. (July 6, 2011), "Gov't eyes other labor markets for maids," Philippine Daily Inquirer.

7. See Philippine Daily Inquirer: Bordadora, Norman (July 3, 2011), "Palace: We're sticking to our guns on maids,"; Nigos, Joel V. (July 30, 2011), “'Saudization': A new challenge for gov't, OFWs” [overseas Filipino workers] (editorial), "Playing Hardball", July 6, 2011; "Binay backs House measure granting househelp benefits," July 19, 2011; Tubeza, Philip C. (July 3, 2011), "CBCP [Catholic Bishops' Conference of the Philippines] welcomes Saudi ban on maids".

8. Philippine Daily Inquirer, "Pinoy maid testifies in US trial of UAE Navy officer," July 20, 2011.

9. Tan Michael L. (2011), "Saudi" (In Pinoy Kasi [Because Filipino]), Philippine Daily Inquirer.

10. Yamani, Mai (June 2011), “Are Saudi women next?", http://www.maiyamani.com/articles.htm.

11. Yamani, Mai (June 2011), “Are Saudi women next?”, http://www.maiyamani.com/articles.htm.

12. Perez, Rob (October 9, 2011), "Filipinas Rise Against Abuse," Honolulu Star Advertiser.

13. See http://www.the daily beast.com/articles/2011/09/18/best-and-worst-countries-for-women-from-icelandto-the-u-s-to-pakistan-and-afghanistan.html; http:// global nation.inquirer.net/13583/in-asia-philippinesis-the-best-place-to-be-a-woman; http://www.philstar.com/Article.aspx?articled=729665.

\section{References}

C. Quebral, Nora (2012) Development Communication Primer. Penang, Malaysia: Southbound. Published online at http://www.southbound.com.my/downloads/QuebralCruzPrimer2012.pdf 